\title{
THE EARLY SARMATIAN SITES OF THE OREL-SAMARA INTERFLUVE
}

\author{
Aleksandr V. Symonenko \\ Institute of Archaeology, National Academy of Sciences of Ukraine, Kyiv, Ukraine
}

\begin{abstract}
The paper critically analyzes the burials of the Orel-Samara interfluve published as the early Sarmatian assemblages. Due to wrongly determined ceramics and confusion in numbering of barrows and other subjective reasons they were interpreted and dated incorrectly. The paper offers the objective analysis of the sites under discussion and their real dating. The collection of Dr. Kostenko presents two burials (Spasskoye-Verkhnyaya Maevka, Pereshchepino) belonging to Belozerka culture, one (Novo-Podkryazh) belonging to Catacomb culture, several Sarmatian burials (Podgorodnoye, Aleksandrovka, Sokolovo), which were dated incorrectly (they belong to the later period in fact). In general, only 10 burials of the region can be dated to the $2^{\text {nd }}-1^{\text {st }}$ centuries $\mathrm{BC}$ out of 22 , which are considered early Sarmatian. These are the burials with Middle La Tune fibulae (Zhemchuzhnoe, Bogdanovka, Lychkovo), mirrors of early types (Sokolovo, Proletarskoe) and the swords with crescent pommel (Zhemchuzhnoe, Terny, Preobrazhenka), with early Sarmatian ceramics (Kolpakovka). The "hoard" from Bulakhivka with silver bowls of the "real cone" type, phalerae and the cauldron of early shape also belongs to this time. According to the funeral rite and burial goods they indeed do not differ from the whole massif of the North Pontic region burials. These are inserted burials oriented mainly in the northern sector. The Orel-Samara interfluve was the north-western periphery of the Rhoxolans lands.

Key words: Orel, Samara, Sarmatians, the early Sarmatian period, barrow, burial, dating, fibula, mirror.

Citation. Symonenko A.V., 2019. The Early Sarmatian Sites of the Orel-Samara Interfluve. The Lower Volga Archaeological Bulletin, vol. 18, no. 1, pp. 81-96. (in Russian). DOI: https://doi.org/10.15688/nav.jvolsu.2019.1.7

Дата поступления статьи: 04.02.2019

ББК 63.422(2)-427

Дата принятия статьи: 10.03.2019
\end{abstract}

\section{РАННЕСАРМАТСКИЕ ПАМЯТНИКИ ОРЕЛЬ-САМАРСКОГО МЕЖДУРЕЧЬЯ}

\author{
Александр Владимирович Симоненко \\ Институт археологии Национальной академии наук Украины, г. Киев, Украина
}

\begin{abstract}
Аннотация. В статье критически анализируются погребения междуречья Орели и Самары, опубликованные в свое время как раннесарматские. В силу ошибочных определений керамики, путаницы в нумерации курганов и других субъективных причин они были неверно интерпретированы и датированы. В статье предлагается объективный анализ спорных памятников и их реальная датировка. Из подборки В.И. Костенко два погребения (Спасское - Верхняя Маевка, Перещепино) относятся к белозерской культуре, одно (Ново-Подкряж) - к катакомбной, несколько сарматских погребений (Подгородное, Александровка, Соколово) датированы неверно и на самом деле более поздние. В целом, из 22 погребений региона, считающихся раннесарматскими, только 10 можно датировать II-I вв. до н.э. Это погребения со среднелатенскими фибулами (Жемчужное, Богдановка, Лычково), ранними зеркалами (Соколово, Пролетарское) и клинками с серповидным навершием (Жемчужное, Терны, Преображенка), с прохоровской керамикой (Колпаковка). К этомуже времени относится «клад» из Булаховки с серебряныㄱ. ми коническими чашами, фаларами и ранним котлом. По обряду и инвентарю они практически не отличаются от юٔ всего причерноморского массива. Это впускные погребения, ориентированные преимущественно в северном секторе. Орель-Самарское междуречье представляло собой северо-западную периферию земель роксолан.

Ключевые слова: Орель, Самара, сарматы, раннесарматский период, курган, погребение, датировка, фибула, зеркало.

Цитирование. Симоненко А. В., 2019. Раннесарматские памятники Орель-Самарского междуречья // Нижневолжский археологический вестник. Т. 18, № 1. С. 81-96. DOI: https://doi.org/10.15688/nav.jvolsu.2019.1.7
\end{abstract}


В степях бассейнов левых притоков Днепра, Орели и Самары обитали многочисленные племена сарматов, а здешний массив сарматских памятников составляет представительную локальную группу, заслуживающую отдельного изучения.

Планомерное исследование археологических памятников в бассейнах Орели и Самары началось в 1972 г. работами археологической экспедиции ИА АН УССР под руководством Д.Я. Телегина в зоне строительства канала «Днепр-Донбасс». В этом же году начались многолетние раскопки экспедиций Днепропетровского национального университета в зонах строительства ОС в Днепропетровской области. Благодаря интенсивным полевым исследованиям И.Ф. Ковалевой, В.И. Костенко, В.А. Ромашко, З.П. Мариной и др. в 1970-х - 80-х гг. здесь открыто более 200 сарматских погребений, в их числе - один из могильников «восточной волны» у с. Подгородное [Ковалева, Костенко, 1976, с. 79-95].

Сарматские памятники, раскопанные экспедициями ДНУ, опубликованы в двух монографиях и нескольких статьях В.И. Костенко (см. список литературы). Хронологические рамки одной из монографий [Костенко, 1983] ограничены III в. до н.э. - III в. н.э., территориальные - междуречьем Дона и Днепра. Вторая книга [Костенко, 1986] посвящена памятникам III в. до н.э. - IV в. н.э. междуречья Орели и Самары. К сожалению, большинство работ В.И. Костенко было опубликовано малым тиражом в провинциальных изданиях (лишь одна статья вышла в «Советской археологии»), и еще при жизни автора они стали библиографической редкостью.

Следует сказать, что взгляды В.И. Костенко сформировались под влиянием идей К.Ф. Смирнова, прежде всего, - его представлений о времени и характере проникновения сарматов в Северное Причерноморье. Не избежал В.И. Костенко и некоторых ошибок своего учителя, полностью поддерживая его положения и пользуясь выделенным им материалом [Полин, Симоненко, 1990, с. 77]. Характеризуя памятники раннесарматского периода, В.И. Костенко выделил три группы: III в. до н.э., III-II вв. до н.э. и ІІ в. до н.э. Памятники первой группы, по мнению исследователя, отражают факт «нестабильности во- енно-политической ситуации в Северном Причерноморье». Вторая группа памятников соответствует «времени появления языгов и роксолан на берегах Днепра» [Костенко, 1982, c. 71-72]. Наконец, памятники третьей группы (во всяком случае, конца II или рубежа II I вв. до н.э.) «принадлежат уже другой культуpe, среднесарматской» [Костенко, 1983, с. 70].

Эти выводы базировались на материалах тех памятников между Доном и Днепром, которые В.И. Костенко и его учитель К.Ф. Смирнов считали раннесарматскими. После ревизии выяснилось, что часть погребений была определена или датирована ошибочно [Полин, Симоненко, 1990].

Между тем памятники Орель-Самарского междуречья весьма важны для понимания археологической картины Северного Причерноморья в раннесарматское время. Внимательное исследование отчетов экспедиций ДНУ в архиве ИА НАНУ и материалов в фондах Кабинета археологии ДНУ выявили то удручающее обстоятельство, что работы В.И. Костенко страдают ошибками и путаницей, а рисунки вещей в них весьма далеки от оригинала. Увы, преждевременная смерть коллеги сделала невозможной полноценную полемику с ним, поэтому критические замечания, изложенные здесь, имеют целью лишь восстановить истину и предупредить умножение ошибок, что часто бывает при работе с чужими материалами.

Ниже предлагается анализ погребений Орель-Самарского междуречья, опубликованных как раннесарматские.

Спасское Новомосковского р-на, кура. 4., nогр. 4. По мнению В.И. Костенко, «наиболее ранними ... являются погребения у сел Спасское и Верхняя Маевка, в которых обнаружены лепные горшки с налепными валиками по линии плеча, прочерченными горизонтальными и свисающими вниз вертикальными линиями. Аналогичные орнаменты известны на сосудах прохоровской культуры. Раннюю дату спасского погребения подтверждает и железный “площик”, довольно близкий железным наконечникам стрел в раннесарматских погребениях и поселениях на Среднем Дону» [Костенко, 1986, с. 37] ${ }^{1}$.

Как было установлено [Полин, Симоненко, 1990, с. 92, 93], сосуд из погр. 4 кург. 4 у 
с. Спасское относится к белозерской культуре. Он был найден между лежавшими на одном уровне в насыпи кургана скелетами (рис. $1,1,2$ ), один из которых (вытянутый) нарушил другой (скорченный). Последнее захоронение, относящееся к белозерской культуре, и сопровождал этот горшок (рис. 1,3), причисленный В.И. Костенко к раннесарматским ${ }^{2}$. Сопровождавший вытянутое захоронение железный «площик» [Костенко, 1983, с. 50], скорее всего, является не наконечником стрелы, а ножом (рис. 1,4). Нахождение его на тазу скелета лишь подтверждает это предположение.

Верхняя Маевка Диепропетровского p-на, гр. XIV, кург. 3, погр. 6. В публикации В.И. Костенко [Костенко, 1979, с. 190] сказано, что погребальное сооружение представляло собой разрушенную грабителем яму с подбоем, где были обнаружены «кости скелета человека со следами медных окислов» $\left[\right.$ Костенко, 1979, с. 190] ${ }^{3}$. В.И. Костенко считал, что «с погребением связана находка лепного горшка» (рис. 1,5). Однако согласно полевой документации [Ковалева, 1974, с. 122] этот сосуд найден в поле соседнего кург. 4. По непонятным причинам В.И. Костенко объединил находки из двух курганов в один комплекс, а в дальнейшем исключил из его состава фрагменты красноглиняной керамики, найденной в заполнении погр. 6 [Ковалева, 1974, с. 118, 119]. «Комплекс» из Верхней Маевки никак не может свидетельствовать о проникновении сарматов в Северное Причерноморье в III-II вв. до н.э., хотя горшок из кург. 4 орнаментирован характерными для прохоровской культуры свисающими линиями.

Перещепино Новомосковского р-на, кург. 1, погр. 10. В изголовье могилы находился горшок (рис. 1,6,7), близкий по форме горшку из Днепростроя (рис. 1,8), по мнению К.Ф. Смирнова [Смирнов 1984, с. 105], повторенному В.И. Костенко [Костенко, 1986, с. 40]. Общность формы обоих сосудов исчерпывается округлым дном, а по тесту и характеру лощения горшок из Перещепина близок белозерской посуде, но обряд говорит о киммерийском времени как наиболее вероятной дате погребения [Полин, Симоненко, 1990, с. 93].

Подгородное Днепропетровского р-на, zp. X, кург. 12, погр. 1. По данным В.И. Костенко, здесь среди трехлопастных черешко- вых наконечников стрел обнаружены два экземпляра с внутренней втулкой. Это обстоятельство дало ему основание датировать памятник «возможно, даже I в. до н.э.» [Костенко, 1986, с. 41]. Я исследовал de visu наконечники из этой могилы и обнаружил там лишь черешковые. Должен заметить, что, в отличие от скифов, сарматы не имели наконечников с «внутренней втулкой» - втулки раннесарматских наконечников длинные, выступающие. Думаю, что в определении обсуждаемых наконечников В.И. Костенко просто ошибся.

Подгородное, гр. ИІІ, кург. 3, погр. 8. Это погребение опубликовано В.И. Костенко и К.Ф. Смирновым как раннесарматское конца II в. до н.э. - начала I в. н.э. [Костенко, 1979 , с.190-192, рис. $1,6-9 ; 1986$, с. 39 , табл. 27,28-37; Смирнов, 1984, с. 107, 108, рис. 47,8-11]. Оно датировано так по наличию краснолаковой чаши (рис. 2,1,5) «эллинистического времени» [Смирнов, 1984, с. 107] и зеркала Хазанов VI, якобы происходящего из этой могилы (рис. 2,2 ). Но согласно отчету [Ковалева, 1973, с. 79, 80, рис. 213] в этом погребении найдено зеркало-подвеска типа Хазанов IX (рис. 2,6), а значит комплекс не старше середины I в. н.э. Зеркало Хазанов VI появилось в нем в статье В.И. Костенко [Костенко, 1979], а в действительности оно найдено, скорее всего, в соседнем кург. $5^{4}$. Это не первый случай путаницы материалов в работах В.И. Костенко. К.Ф. Смирнов доверял своему ученику и воспроизвел его материалы в своей книге.

Александровка Новомосковского р-на, кypz. 13. В заполнении большой ямы основного погребения среди ошлакованного грунта обнаружены фрагменты гончарного красноглиняного кувшина. «Исследования стратиграфии александровского кургана и анализ фрагментов вещей из погребального комплекса» [Костенко, 1986, с. 40] позволили В.И. Костенко отнести его погребение к концу II - I в. до н.э. [Костенко, 1979, с. 196].

Правильность этой датировки вызывает сильные сомнения. Во-первых, основные погребения в больших ямах характерны для среднесарматской культуры - почти все раннесарматские погребения Северного Причерноморья впущены в курганы эпохи бронзы 
[Симоненко, 1994, с. 33-35]. Во-вторых, «фрагменты вещей» из этого комплекса представляют собой несколько невыразительных обломков красноглиняного сосуда (скорее всего, античного кувшина первых веков н.э.) и лепного горшка. Оснований датировать эту могилу именно раннесарматским временем нет.

Соколово Новомосковского р-на, гр. II, кypz. 3, nогр. 2. В насыпи обнаружен скелет женщины, сопровождавшийся нижней частью красноглиняного кувшина, костяной проколкой, бусами и фрагментом бронзовой проволоки. Проколки известны в погребениях прохоровской культуры IV-III вв. до н.э. [Смирнов, 1984, c. 89]. В.И. Костенко заметил, что «столь ранним временем датировать комплекс не позволяют бусы, хронологические рамки существования которых охватывают первые века н.э.» [Костенко, 1986, с. 40, 41]. Поэтому совершенно непонятно, почему он «ограничивает время комплекса I в. до н.э.». Уточнить дату погребения может фрагмент бусины Алексеева 57 - бусы этого типа характерны для I-IV вв. н.э., особенно для I-III вв. [Алексеева, 1978, c. 67]. Таким образом, этот комплекс не может быть старше I в. н.э.

Безоговорочно к раннесарматскому времени можно отнести следующие памятники Орель-Самарского междуречья.

Жемчужное Юрьевского р-на, кург. 2, nогр. 1. Впускное захоронение в яме, контуры которой не прослеживались. Скелет частично разрушен, лежал вытянуто на спине, головой на С. В комплексе - фрагментированная бронзовая проволочная одночленная фибула среднелатенской схемы с деревянной осью пружины, железный черешковый трехлопастный наконечник стрелы, нож и оселок [Ковалева, 1986, с. 22-24, рис. 39-42, 47-50].

Лычково Новомосковского р-на, гр. III, кург. 1, погр. 1. Впускное в деревянной прямоугольной колоде. Скелет лежал вытянуто на спине, головой на СВ. В комплексе - бронзовая фибула «зарубинецкого» типа с треугольным щитком, железный наконечник копья, гончарный красноглиняный кувшин, рядом с которым обнаружены кости передней конечности и лопатки овцы (рис. 3,1-3) [Костенко, 1986, с. 23, табл. 15:1-3].

Богдановка Павлоградского р-на гр. 4, кург. 3, погр. 3. Впускное в яме, контуры ко- торой не прослежены. Скелет молодой девушки лежал вытянуто на спине, головой на ССВ. Погребение сопровождалось бронзовой фибулой «неапольского» варианта (фрагментирована) и глиняным пряслицем (рис. 3,4-б) [Марина, Ромашко, 1984, с. 64, рис. 234-236].

Все перечисленные застежки датируются второй половиной I в. до н.э. [Кропотов, 2010, c. 58].

Терны Юрьевского р-на, гр. I, кург. 4, nozp. 20. Разрушенное грабителями впускное погребение. При разборке грабительской воронки встречены угольки и фрагменты красноглиняной античной керамики. Здесь же найден железный меч (рис. 4,1) с серповидным навершием и прямым перекрестьем [Ковалева и др., 1984, с. 40, рис. 85; Костенко, 1986, табл. 6,15; Симоненко, 2015, с. 25 , рис. 2,4].

Жемчужнно, кург. 2, погр. 3. Впускное в катакомбе-«чулке» с круглой входной ямой (рис. 4,2 ). Скелет лежал вытянуто на спине, головой на СЗ. За черепом - нога овцы и несколько угольков. На груди, от подбородка к животу, лежал железный меч с серповидным навершием и прямым перекрестьем (рис. 4,3 ). Рядом с левым голеностопом - курильница (рис. 4,4) [Ковалева, 1986, с. 22-24, рис. 39-42, 47-50; Симоненко, 2015, с. 25 , рис. 2,6].

Преображенка, гр. II, кург. 2, погр. 4. Впускное в яме, контуры которой не прослеживались. Скелет лежал вытянуто на спине, головой на С3 (рис. 4,5). Сопровождалось железным мечом с серповидным навершием и прямым перекрестием (рис. 4,6), античным кувшином (рис. 4,7) и напутственной пищей с ножом [Симоненко, 2015, с. 25, рис. 3,2,3].

Могилы в Преображенке и Жемчужном могут быть датированы не ранее I в. до н.э. [Симоненко, 2015, с. 26-28]. Дату меча из Тернов нельзя уточнить по сопровождающему материалу, но по морфологическим признакам он не древнее II в. до н.э. Раннесарматскую культурную принадлежность могил со среднелатенскими фибулами и оружием с серповидным навершием подтверждает и погребальный обряд: это доминирующие во II-I вв. до н.э. впускные могилы с ориентировкой погребенных в северный сектор [Симоненко, 1994 , c. 35-37].

Соколово Новомосковского р-на, кург. 1 "Червона могила", погр. 1. Впускное в уз- 
кой яме. Скелет женщины лежал вытянуто на спине, головой на С (рис. 5,1). В состав погребального инвентаря входили: бронзовое зеркало типа Хазанов IV - с ручкой-штырем, валиком по краю диска и выгравированным изображением шестилепестковой розетки (рис. 5,2), бронзовая фибула-брошь с изображением всадника (рис. 5,3), красноглиняный кувшин с яйцевидным корпусом и витой ручкой (рис. 5,4), красноглиняные флаконыбальзамарии (рис. 5,5,6), две лепные курильницы в виде острореберной миски и бочонка (рис. 5,7,8), лепное биконическое прясло (рис. 5,9), железный нож (рис. 5,10), две золотые серьги (рис. 5,11), разнообразные бусы (рис. 5,12-15), среди которых две бусиныличины из «финикийского стекла» (рис. 5,14$)$ [Костенко, 1979, с. 192-196, рис. 3, 4]. Такие вещи достаточно хорошо известны в материалах античных центров Северного Причерноморья, а также в сарматских погребениях конца II - I в. до н.э.

\section{Пролетарское Новомосковского р-на,} гр. $\mathrm{XXX}$, кург. 11, погр. 1. Впускное погребение в яме, контуры которой не прослежены. Скелет женщины лежал вытянуто на спине, головой на СВ. Справа от черепа - кости жертвенной пищи (передний отруб баранины). В комплекс входили фрагменты бронзового круглого зеркала диаметром 13 см с вертикальным бортиком по краю, керамическое прясло, железный нож, бусы [Костенко, 1986, c. 27 , табл. 11,17$]$. Ближайший аналог среди украинских находок - зеркало из погребения у с. Фрунзе на р. Северский Донец [Смирнов, 1984, с. 90, 91, рис. 42,2]. В датировке аналогичных изделий у исследователей имеются расхождения. М.Г. Мошкова считает, что наиболее распространенными они были в прохоровских погребениях III-ІІ вв. до н.э. [Мошкова, 1963, c. 42]. Несколько иного мнения придерживался В.П. Шилов, указывавший, что зеркала с вертикальным бортиком существуют у меотов с конца III по начало I в. до н.э. [Шилов, 1975, c. 121, 122]. В сарматских памятниках Кубани такие зеркала по современной хронологии датируются второй половиной IV - II в. до н.э. [Лимберис, Марченко, 1991, с. 64].

Колпаковка Магдалиновского р-на, гp. XXVI, кург. 4, погр. 1. Погребение в катакомбе так называемого «ворухского» типа (рис. 5,16). По мнению В.И. Костенко, оно относится к раннесарматскому времени. Там обнаружен лепной кувшин с корпусом грушевидной формы, отделенным от венчика врезными линиями со свисающими от них вертикально вниз пучками из четырех линий (рис. 5,17$)$. Наиболее часто сосуды подобного типа встречаются в памятниках Прикубанья и Предкавказья II-I вв. до н.э. Анализ погребального обряда, а также хронология описанных сосудов позволяют, по мнению В.И. Костенко, ограничить время колпаковского захоронения II в. до н.э., возможно, его концом [Костенко, 1982, с. 73].

Булаховка Павлоградского р-на, урочище Круглик, кург. 1. Одним из наиболее ярких комплексов междуречья является комплекс находок в насыпи кургана, куда входили серебряные чаши (рис. 6,1-3) и фалары (рис. 6,6; 7,1-4), бронзовый котел (рис. 6,5), золотые бляшки от одежды, бляшки и кольца от конской упряжи (рис. 6,6-9). Он входит в круг аналогичных памятников конца III - I в. до н.э. (Федуловский и Таганрогский клады, Старобельск, Янчокрак, Балаклея и др.). В.И. Костенко вслед за К.Ф. Смирновым считал, что такие комплексы являются разрушенными захоронениями представителей сарматской военной аристократии или родоплеменной знати [Костенко, 1978, с. 85]. Боюсь, что это не совсем так. Если некоторые находки фаларов в Азиатской Сарматии (Жутово, кург. 27) и можно связать с погребениями в том же кургане, то фалары II-I вв. до н.э. в Северном Причерноморье найдены преимущественно в так называемых «кладах», то есть ритуальных депозитах без следов человеческого захоронения. Пожалуй, лишь находки у Твардицы и Балаклеи могут быть связаны с погребениями, однако в обоих случаях сведения недостоверны. «Клады» с фаларами, как правило, найдены в насыпях курганов или в естественных возвышенностях без следов погребения.

Таким образом, вместо 22 памятников III-I вв. до н.э., выделенных В.И. Костенко [Костенко, 1986, с. 41], в Орель-Самарском междуречье с уверенностью можно выделить только 10 комплексов II-І вв. до н.э. Возможно, горшок из кург. 4. у Верхней Маевки также датируется этим временем. Кроме него 
и «клада» из Булаховки, остальные памятники - впускные погребения, ориентированные в северном секторе, как и большинство раннесарматских захоронений Северного Причерноморья.

Раннесарматские памятники исследуемой территории датируются не ранее II в. до н.э. Некоторые погребения I в. до н.э. хорошо маркированы среднелатенскими фибулами «неапольского» варианта (Жемчужное, Богдановка) и зарубинецкого типа (Лычково). Часть погребений, датированных II-І вв. до н.э., могла быть совершена именно в I в. до н.э. несовершенство нашей хронологии не позволяет уточнить их дату. По обряду и инвентарю они практически не отличаются от всего причерноморского массива. Это впускные погребения, ориентированные преимущественно в северном секторе. Орель-Самарское междуречье представляло собой северо-западную периферию земель роксолан - дальше на север раннесарматские памятники единичны (Битица, Жовнин).

Малочисленность раннесарматских погребений в регионе В.И. Костенко объяснял несколькими причинами [Костенко, 1986, c. 66]. По его мнению, вследствие распашки курганов погибают, как правило, в первую очередь погребения в верхней части насыпи. Однако отсутствие объекта не является доказательством его возможного наличия. Ближе к истине еще одна причина, предложенная В.И. Костенко, - малочисленность раннесарматских комплексов может быть свидетельством незначительности кочевнических отрядов, проникнувших в междуречье. Косвенное подтверждение этому исследователь видел во времени возникновения Подгороднянского могильника, наиболее раннее погребение которого якобы датируется концом II - началом І в. до н.э. Однако эта могила (гр. VIII, кург. 3, погр. 8) датирована ошибочно - в комплексе было не плоское зеркало Хазанов VI, как считали В.И. Костенко и К.Ф. Смирнов, а зеркало-подвеска типа Хазанов IX, не позволяющее опустить его дату ниже I в. н.э. Таким образом, Подгороднянский могильник не имеет отношения к раннесарматской эпохе, а малочисленность погребений этого времени в Орель-Самарском междуречье соответствует общей картине во всем Северном Причерноморье.

\section{ПРИМЕЧАНИЯ}

${ }^{1}$ В более ранней работе [Костенко 1977, с. 118] и в отчете [Ковалева и др., 1975, с. 64] это погребение фигурирует как найденное в Верхней Маевке. Мне до сих пор не удалось выяснить, в каком же из пунктов - Спасском или Верхней Маевке - оно в действительности находилось.

${ }^{2}$ Следует отметить, что налепной декор керамики появляется у причерноморских сарматов не ранее второй половины ІІ в. н.э. в западных регионах (междуречье Днестра и Прута), вероятно, под влиянием местной дакийской традиции.

${ }^{3} \mathrm{~B}$ отчет не помещены полевые чертежи, а фото этого погребения нет.

${ }^{4}$ В тексте отчета [Ковалева, 1973, с. 85, 86] зеркало не упомянуто, однако внесено в инвентарную опись под № 111 как происходящее из погр. 1 кург. 5 [Ковалева, 1973, опись, с. 25]. Фото зеркала без подписи помещено в альбоме иллюстраций среди материалов из этого погребения [с. 69, рис. 237]. Похоже, что именно это зеркало в публикациях К.Ф. Смирнова и В.И. Костенко по ошибке оказалось среди материалов из погр. 8 кург. 3 . 


\section{ИЛЛЮСТРАЦИИ}
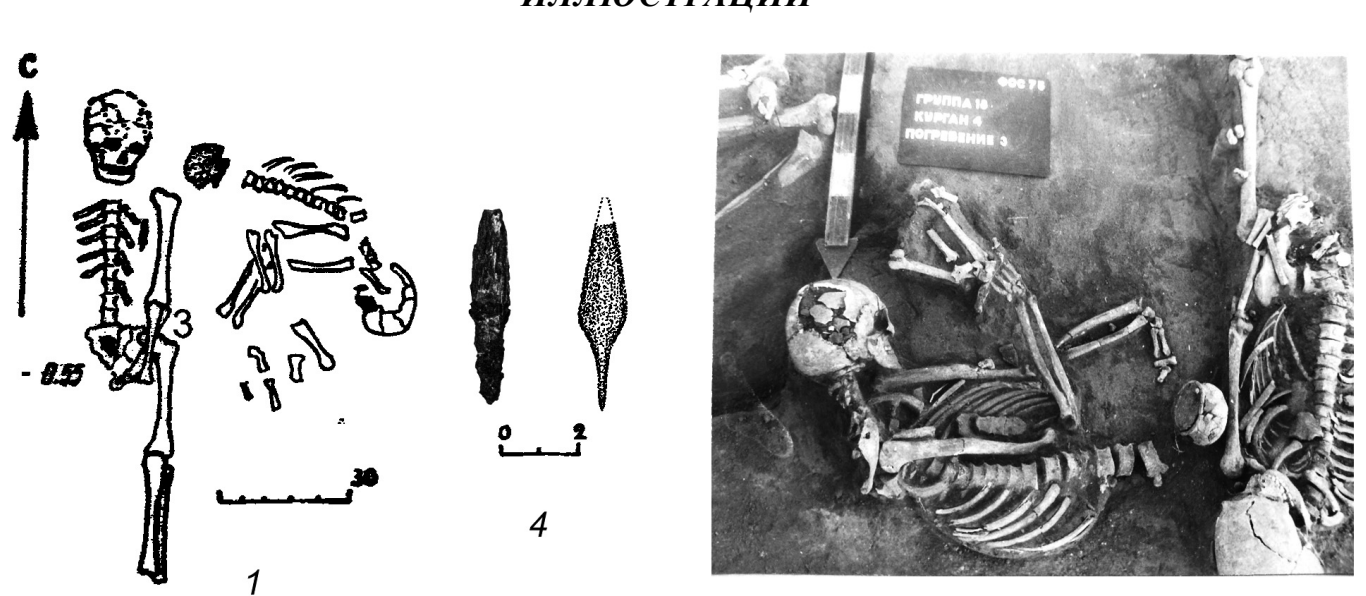

2
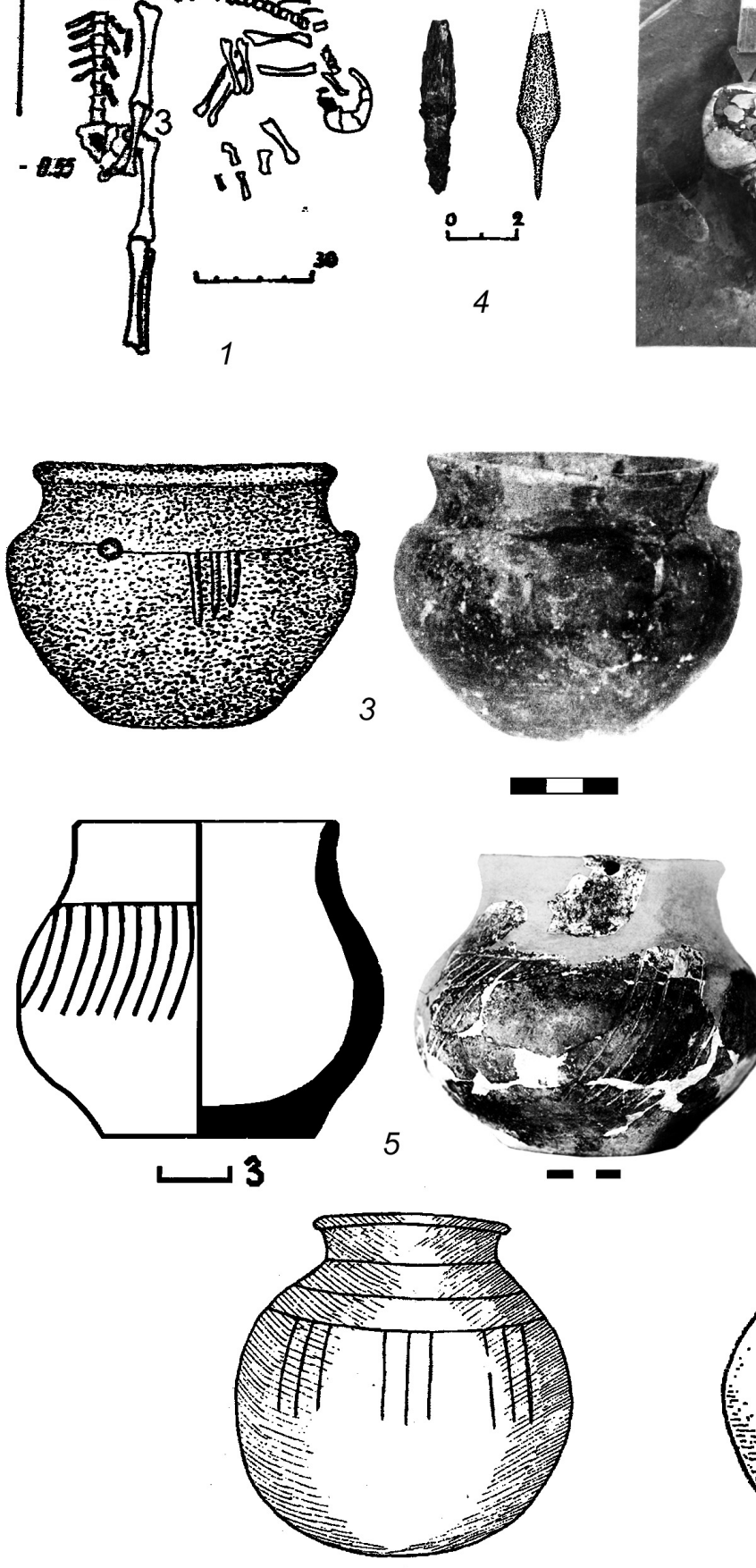

8

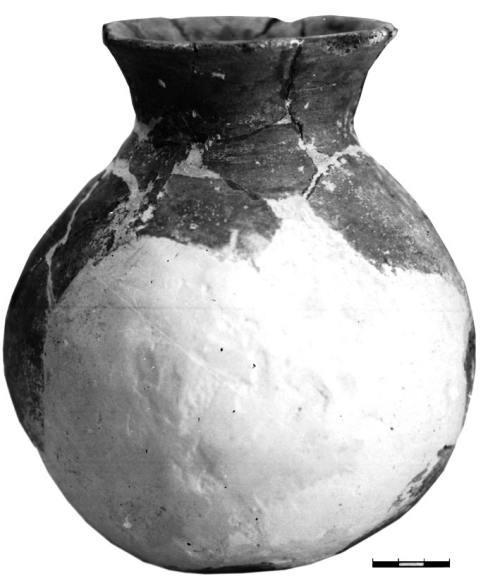

6

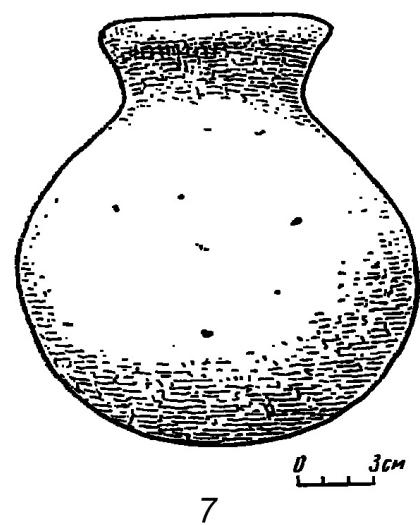

Рис. 1. Погребения эпохи поздней бронзы - раннего железного века, ошибочно определенные как сарматские: 1-4 - Спасское; 5 - Верхняя Маевка; 6 - горшок из Перещепино; 7 - он же [по Смирнов, 1984]; 8 - горшок из раскопок на Днепрозаводстрое

Fig. 1. The late Bronze Age and the early Iron Age burials, which have been wrongly considered Sarmatian: 1-4 - Spasskoe; 5 - Verkhnyaya Maevka; 6 - pot from Pereshchepino; 7 - the same [after Smirnov, 1984]; 8 - pot from Dneprozavodstroy 

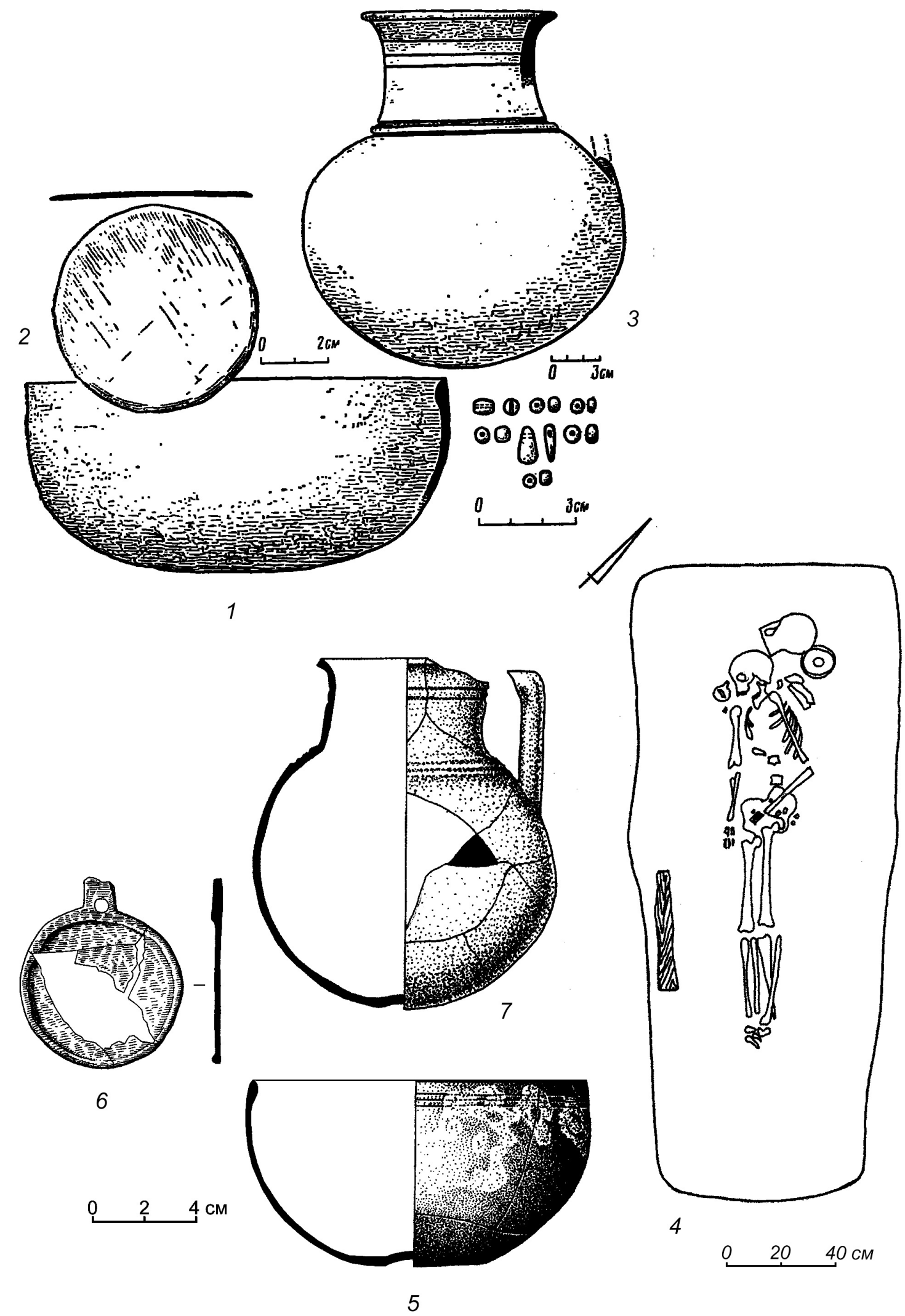

Рис. 2. Подгородное, гр. VIII, кург. 3, погр. 8:

1-3 - [по Смирнов, 1984]; 4-5 - [по Simonenko, Marčenko, Limberis, 2008]

Fig. 2. Podgorodnoe, group 8, barrow 3, burial 8:

1-3 - [after Smirnov 1984]; 4-5 - [after Simonenko, Marčenko, Limberis, 2008] 
A.B. Симоненко. Раннесарматские памятники Орель-Самарского междуречья

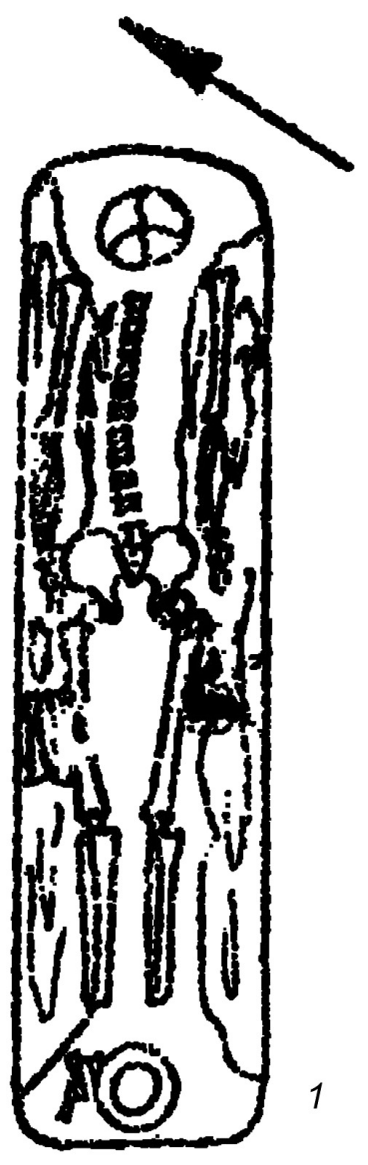

$0 \quad 20 \quad 40 \mathrm{~cm}$
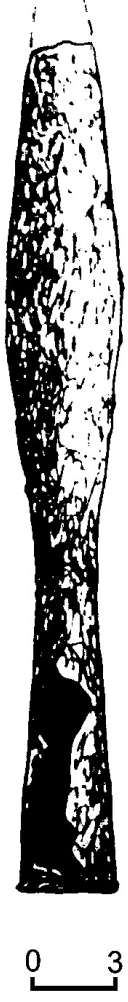
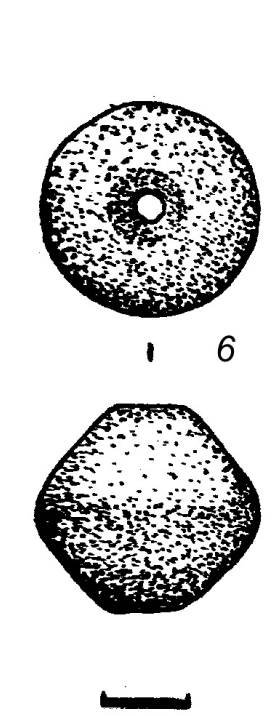

3

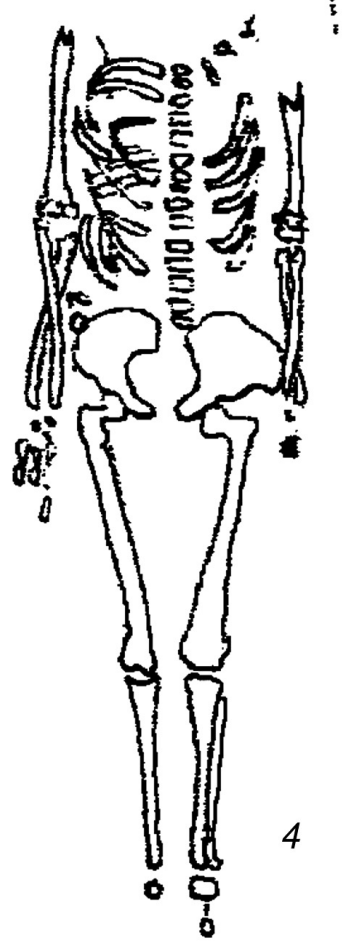

$0 \quad 20 \quad 40 \mathrm{~cm}$

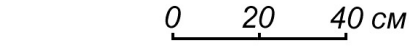

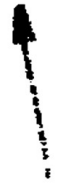
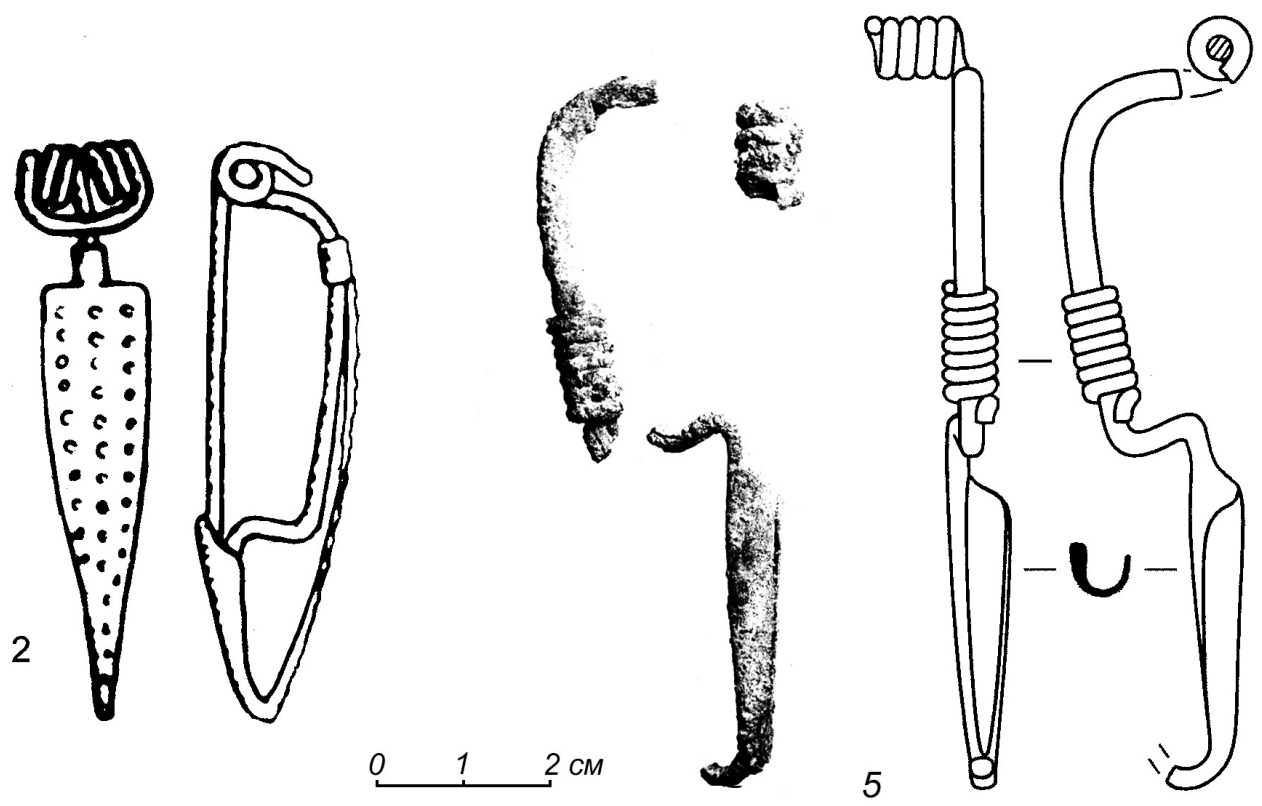

Рис. 3. Раннесарматские погребения междуречья Орели и Самары:

1-3 - Лычково, гр. III, кург. 1, погр. 1 [по Костенко, 1986];

4-6 - Богдановка, гр. 4, кург. 3, погр. 3 [по Марина, Ромашко, 1984]

Fig. 3. The early Sarmatian burials of the Orel-Samara interfluve:

1-3 - Lychkovo, group 3, barrow 1, burial 1 [after Kostenko, 1986];

4-6 - Bogdanovka, group 4, barrow 3, burial 3 [after Marina, Romashko, 1984] 

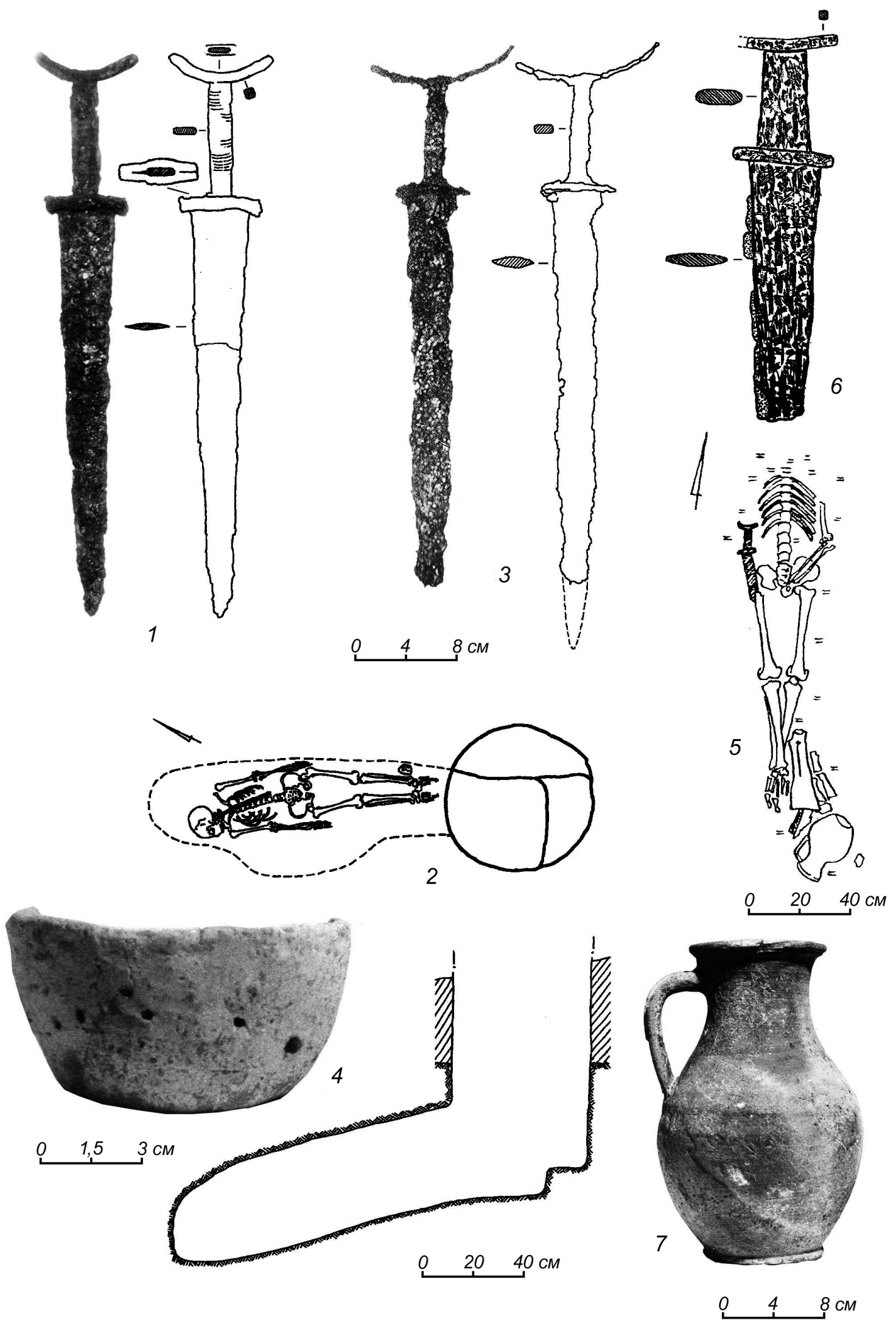

Рис. 4. Раннесарматские погребения междуречья Орели и Самары [по Симоненко, 2015]: 1 - Терны; 2-4 - Жемчужное; 5-7 - Преображенка

Fig. 4. The early Sarmatian burials of the Orel-Samara interfluve [after Symonenko, 2015]: 1-Terny; 2-4 - Zhemchuzhnoe; 5-7 - Preobrazhenka 
А.В. Симоненко. Раннесарматские памятники Орель-Самарского междуречья
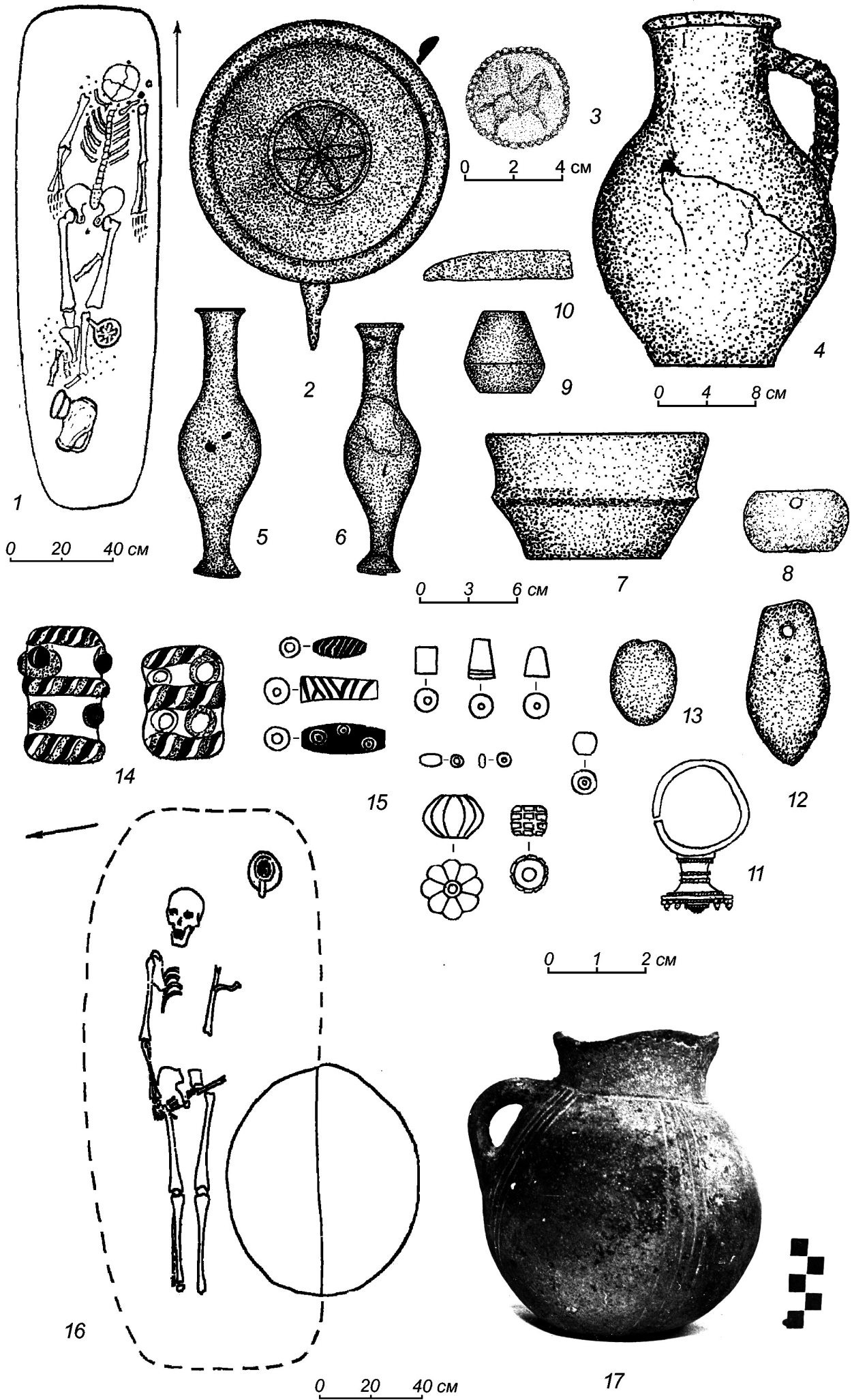

Рис. 5. Раннесарматские погребения междуречья Орели и Самары: 1-15 - Соколово, кург. 1 «Червона могила», погр. 1 [по Костенко, 1979а]; 16-17 - Колпаковка, гр. XXVI, кург. 4, погр. 1 [по Костенко, 1986]

Fig. 5. The early Sarmatian burials of the Orel-Samara interfluve:

1-15 - Sokolovo, barrow 1 "Chervona Mogila", burial 1 [after Kostenko, 1979a]; 16-17 - Kolpakovka, group 26, barrow 4, burial 1 [after Kostenko, 1986] 
A.V. Symonenko. The Early Sarmatian Sites of the Orel-Samara Interfluve
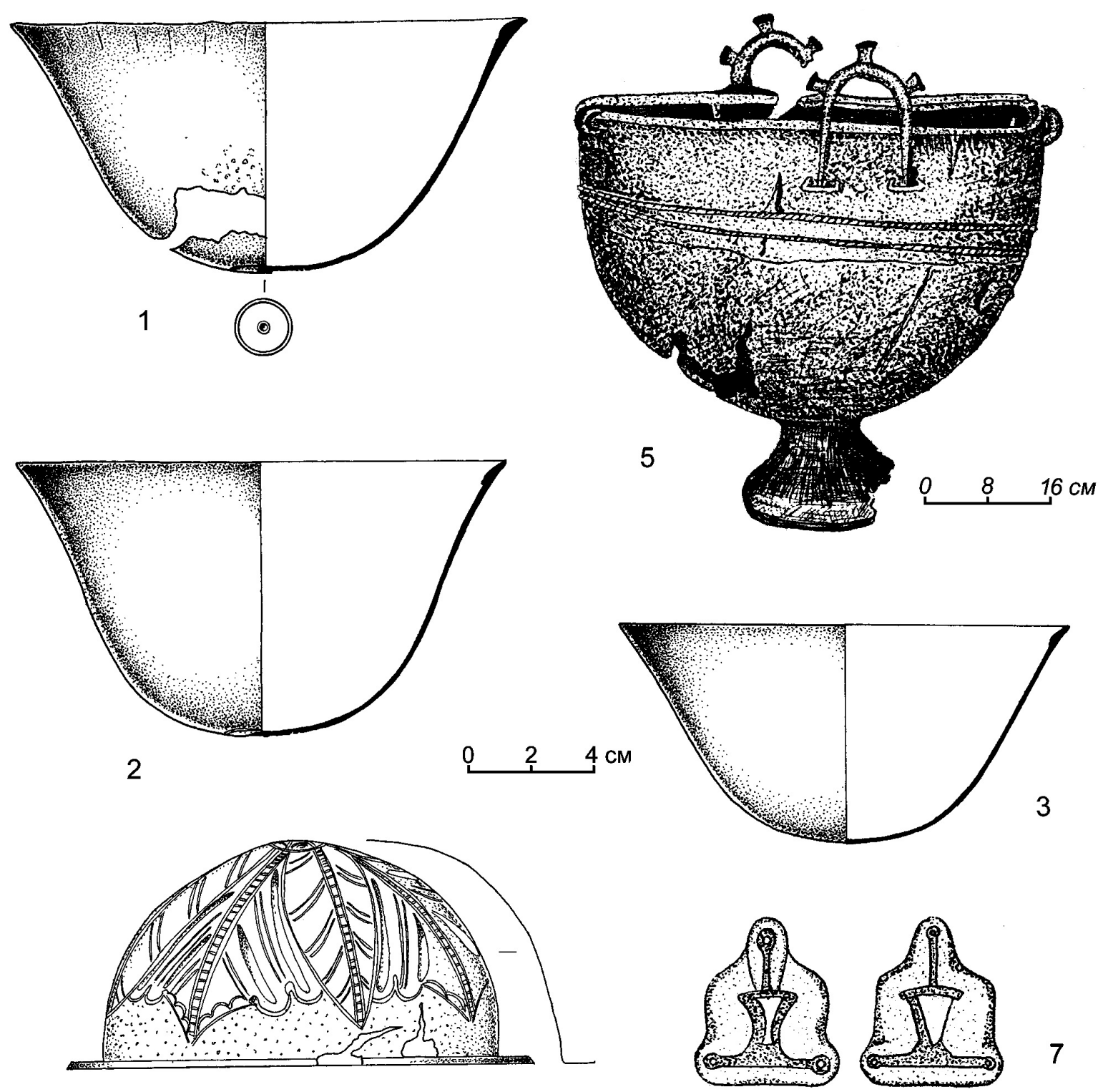

4
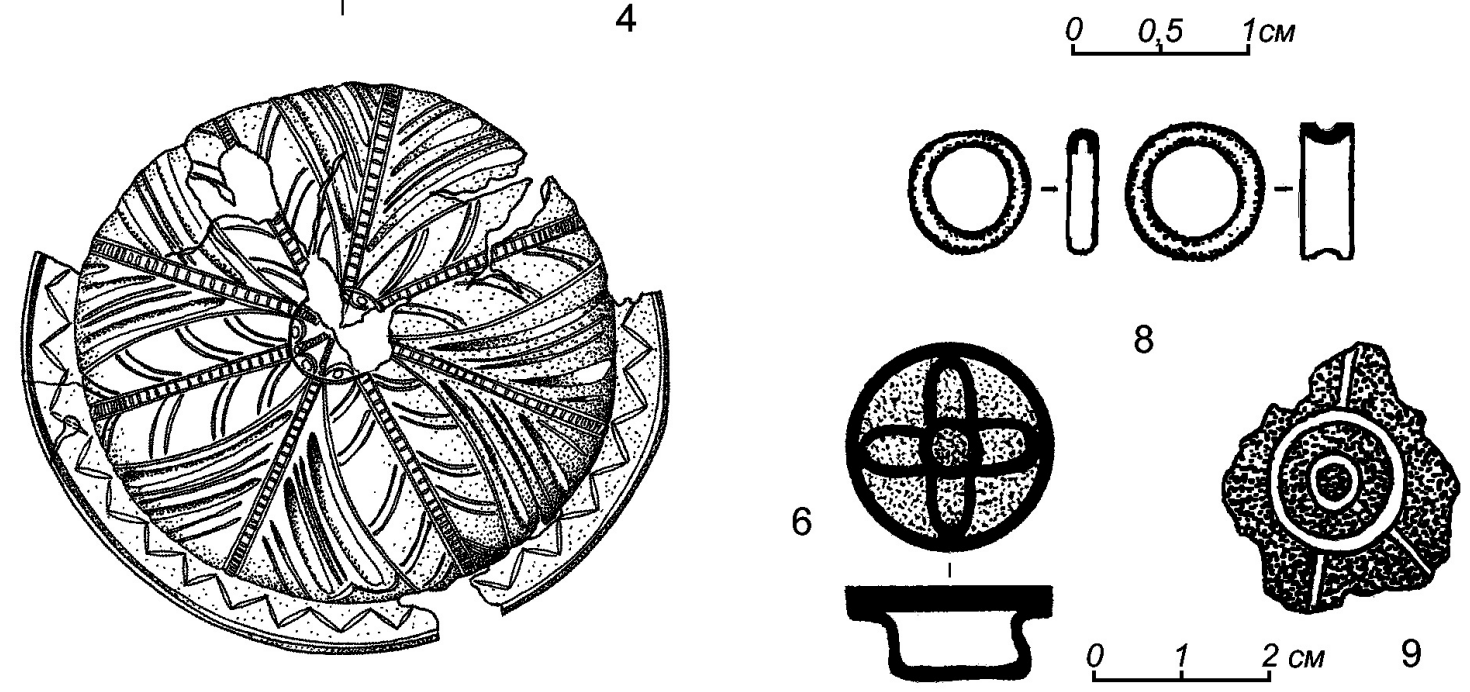

Рис. 6. «Клад» из Булаховки [по Simonenko, Marčenko, Limberis, 2008]

Fig. 6. The "hoard" from Bulakhivka [after Simonenko, Marčenko, Limberis, 2008] 

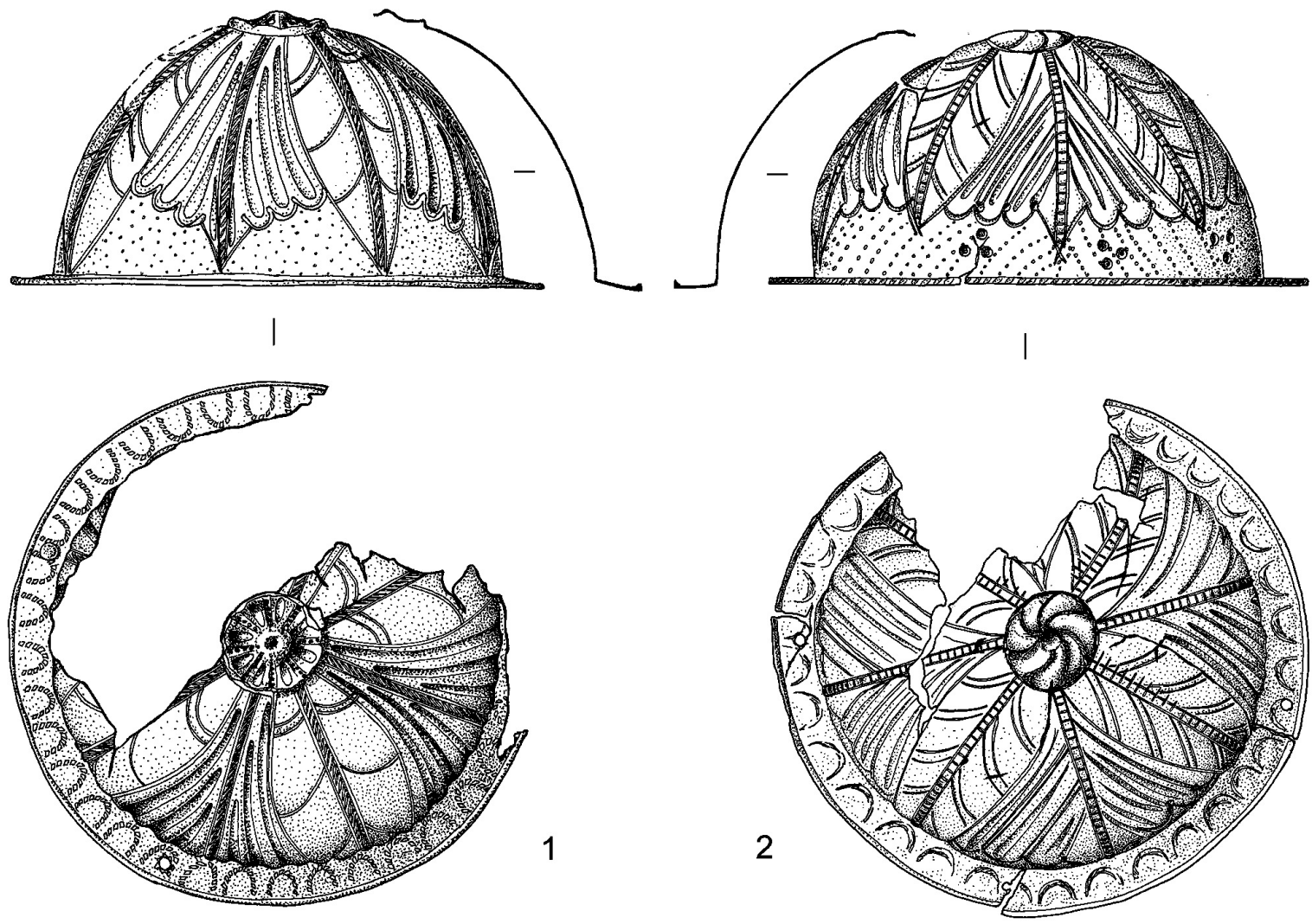

$2 \quad 2 \quad 4 \mathrm{~cm}$
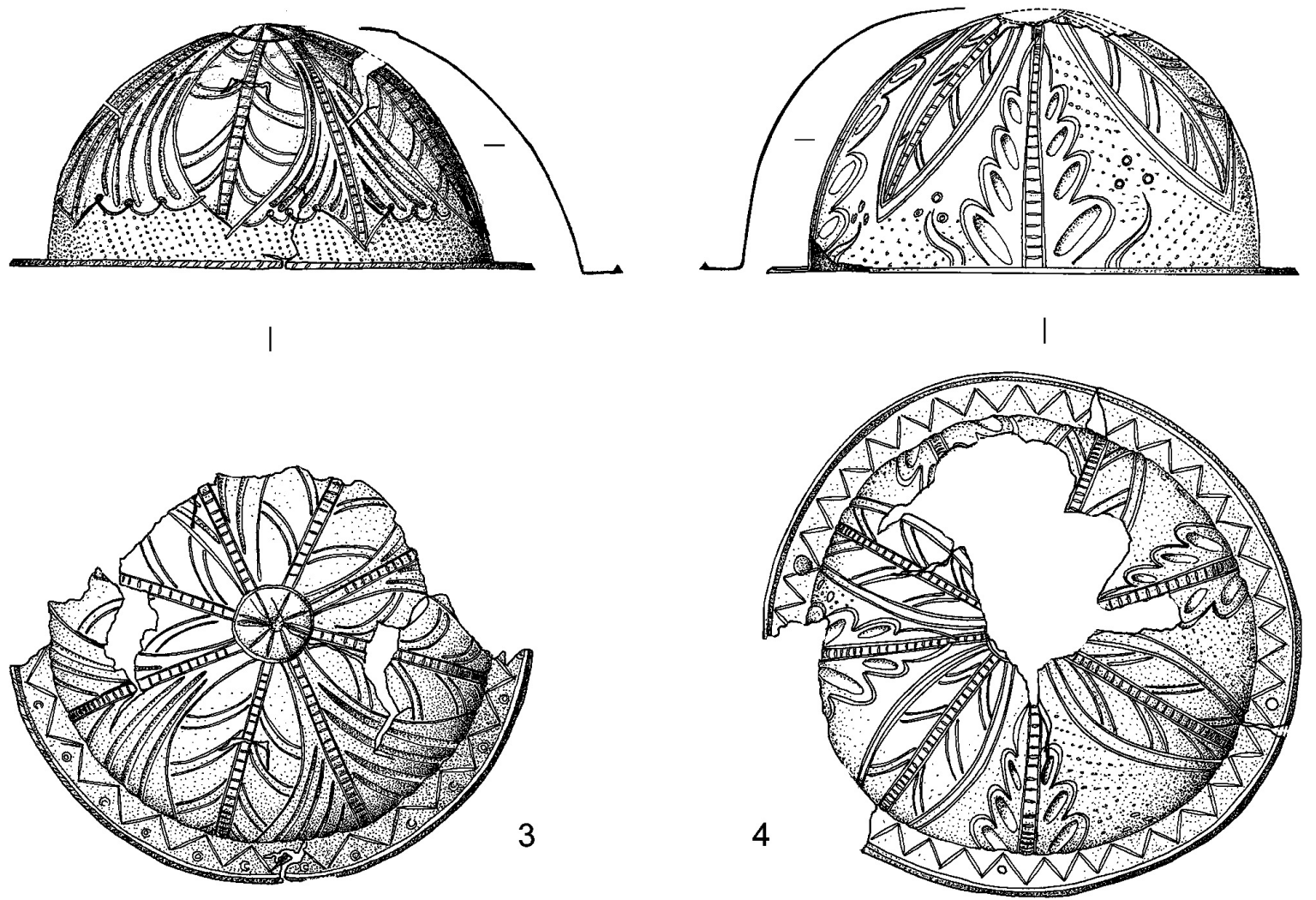

Рис. 7. «Клад» из Булаховки [по Simonenko, Marčenko, Limberis, 2008]

Fig. 7. The "hoard" from Bulakhivka [after Simonenko, Marčenko, Limberis, 2008] 


\section{СПИСОК ЛИТЕРАТУРЫ}

Алексеева Е. М., 1978. Античные бусы Северного Причерноморья. Свод археологических источников. Вып. Г1-12. М. : Наука. 120 c.

Ковалева И. Ф., 1973. Исследование археологических памятников трассы строительства II-ой очереди Фрунзенской оросительной системы (Днепропетровский, Новомосковский и Магдалиновский р-ны Днепропетровской области). Отчет по научно-исследовательской работе (промежуточный этап) // Науковий архів IA НАНУ, № 1973/35.

Ковалева И. Ф., 1974. Исследование археологических памятников трассы строительства II-ой очереди Фрунзенской оросительной системы в 1974 г. // Науковий архів ІА НАНУ, № 1974/40.

Ковалева И. Ф., 1986. Археологические исследования в зонах орошения в Днепропетровской области в 1986 г. // Науковий архів IА НАНУ, № 1986/146.

Ковалева И. Ф., Ковалева В. В., Перетятко В. И., Попцов В. А., 1975. Отчет о научно-исследовательской работе (промежуточный этап). Исследование археологических памятников в зоне строительства Царичанской оросительной системы // Науковий архів ІА НАНУ, № 1975/52.

Ковалева И. Ф., Костенко В. И., 1976. Новые источники по истории сарматских племен Северного Причерноморья (к исследованию Подгороднянских сарматских могильников) // Некоторые вопросы отечественной историографии и источниковедения. Вып. 3. Днепропетровск : Изд-во ДГУ. С. 78-94.

Ковалева И. Ф., Марина З. П., Шалобудов В. И., 1984. Археологические исследования в зонах орошения в Днепропетровской области в 1984 г. // Науковий архів ІА НАНУ, № 1984/146.

Костенко В. И., 1977. Сарматские памятники в материалах археологической экспедиции ДГУ // Курганные древности Степного Поднепровья III-I тыс. до н.э. Днепропетровск : Издво ДГУ. С. 120-128.

Костенко В. И., 1978. Комплекс с фаларами из сарматского погребения у с. Булаховка // Курганные древности степного Поднепровья. Вып. 2. Днепропетровск : Изд-во ДГУ. С. 79-86.

Костенко В. И., 1979. Наиболее ранние сарматские погребения в бассейне рек Орели и Самары // Советская археология. № 4. С. 114-123.

Костенко В. И., 1979а. Сарматы в междуречье Орели и Самары // Курганные древности степного Поднепровья. Вып. 3. Днепропетровск : Изд-во ДГУ. С. 125-139.

Костенко В. И., 1982. Раннесарматский период в истории Северного Причерноморья // Древно- сти степного Поднепровья (III-I тыс. до н.э.). Днепропетровск : Изд-во ДГУ. С. 69-75.

Костенко В. И., 1983. Сарматские памятники Днепро-Донского междуречья III в. до н.э. - середины ІІІ в. н.э. Днепропетровск : Изд-во ДГУ. $103 \mathrm{c}$.

Костенко В. И., 1986. Сарматы Самарско-Орельского междуречья III в. до н.э. - IV в. н.э. Днепропетровск : Изд-во ДГУ. 104 с.

Кропотов В. В., 2010. Фибулы сарматской эпохи. Киев : АДЕФ-Украина. 386 с.

Лимберис Н. Ю., Марченко И. И., 1991. Классификация и хронология зеркал из сарматских погребений Правобережья Кубани // Древности Кубани. Краснодар. С. 63-68.

Марина 3. П., Ромашко В. И., 1984. Археологические исследования в зоне подработок шахт Западного Донбасса в 1984 г. // Науковий архів IA HAHУ, № 1984/147.

Мошкова М. Г., 1963. Памятники прохоровской культуры. Свод археологических источников. Вып. Д1-10. М. : Наука. 56 с. +32 табл.

Полин С. В., Симоненко А. В., 1990. «Раннесарматские» погребения Северного Причерноморья // Исследования по археологии Поднепровья. Днепропетровск : Изд-во ДГУ. С. 76-95.

Симоненко О. В., 1994. Ранньосарматський період в Північному Причорномор'ї // Археологія. № 1. C. 32-48.

Симоненко А. В., 2015. Сарматские всадники Северного Причерноморья. 2-е изд. Киев : Издатель Олег Филюк. 466 с.

Смирнов К.Ф., 1984. Сарматы и утверждение их политического господства в Скифии. М. : Наука. $184 \mathrm{c.}$

Шилов В. П., 1975. Очерки по истории древних племен Нижнего Поволжья. Л. : Наука. 208 с.

Simonenko A. V., Marčenko I. I., Limberis N. Yu., 2008. Römische Importe in sarmatischen und maiotischen Gräbern zwischen Unterer Donau und Kuban. Mainz : Verlag Philipp von Zabern. 626 S.

\section{REFERENCES}

Alekseeva E.M., 1978. The Classic Beads of North Pontic Region. Svod arkheologicheskikh istochnikov, iss 1-12. Moscow, Nauka Publ. 120 p. (in Russian).

Kovaleva I.F., 1973. Field Report about the Archaeological Excavation in the Dnepropetrovsk, Novomoskovsk and Magdalinovo Districts of Dnepropetrovsk Region in 1973. Naukoviy arkhiv Instituta arkheologii NAN Ukrainy, 1973/35. (in Russian). 
Kovaleva I.F., 1974. Field Report about the Archaeological Excavation in the Dnepropetrovsk Region in 1974. Naukoviy arkhiv Instituta arkheologii NAN Ukrainy, 1974/40. (in Russian).

Kovaleva I.F, 1986. Field Report about the Archaeological Excavation in the Dnepropetrovsk Region in 1986. Naukoviy arhiv Instituta arkheologii NAN Ukrainy, 1986/146. (in Russian).

Kovaleva I.F., Kovaleva V.V., Peretyatko V.I., Poptsov V.A., 1975. Field Report about the Archaeological Excavation in the Tsarichanka District of Dnepropetrovsk Region in 1975. Naukoviy arkhiv Instituta arkheologii NAN Ukrainy. 1975/52. (in Russian).

Kovaleva I.F., Kostenko V.I., 1976. New Sources on the History of the Sarmatian Tribes of North Pontic Region (on the Exploration of Podgorodnoe Sarmatian Burial Grounds). Nekotorye voprosy otechestvennoy istoriografii i istochnikovedeniya, iss. 3. Dnepropetrovsk, DSU, pp. 78-94. (in Russian).

Kovaleva I.F., Marina Z.P., Shalobudov V.I., 1984. Archaeological Investigation in Irrigation Zones in the Dnipropetrovsk Region in 1984. Naukoviy arkhiv Instituta arkheologïi NAN Ukrainy, 1984/146. (in Russian).

Kostenko V.I., 1977. Sarmatian Sites among Materials of the Archaeological Expedition of Dnepropetrovsk University. Kurgannye drevnosti Stepnogo Podneprov'ya III-I tys. do n.e. Dnepropetrovsk, DSU, pp. 120-128. (in Russian).

Kostenko V.I., 1978. The Assemblage with Phalerae from Sarmatian Grave near Bulakhovka Village. Kurgannye drevnosti Stepnogo Podneprov'ya, iss. 2. Dnepropetrovsk, DSU, pp. 79-86. (in Russian).

Kostenko V.I., 1979. The Earliest Sarmatian Graves in the Orel and Samara Rivers Basin. Sovetskaya arheologiya, no 4, pp. 114-123. (in Russian).

Kostenko V.I., 1979a. The Sarmatians in Orel and Samara Rivers Interfluve. Kurgannye drevnosti Stepnogo Podneprov'ya, iss. 3. Dnepropetrovsk, DSU, pp. 125-139. (in Russian).

Kostenko V.I., 1982. The Early Sarmatian Period in the History of North Pontic Region. Drevnosti
Stepnogo Podneprov'ya (III-I tys. do n.e.). Dnepropetrovsk, DSU, pp. 69-75. (in Russian). Kostenko V.I., 1983. Sarmatian Sites of Dnieper and Don Interfluve of the $3^{\text {rd }}$ Century $B C-$ mid- $2^{\text {nd }}$ Century AD. Dnepropetrovsk, DSU. 103 p. (in Russian).

Kostenko V.I., 1986. The Sarmatians of the Samara and Orel Interfluve of the $3^{\text {rd }}$ Century $B C$ $4^{\text {th }}$ Century AD. Dnepropetrovsk, DGU. 104 p. (in Russian).

Kropotov V.V., 2010. Fibulae of Sarmatian Age. Kiev, ID “ADEF-Ukraina” Publ. 386 p. (in Russian).

Limberis N.Yu., Marchenko I.I., 1991. The Classification and Chronology of the Mirrors from Sarmatian Graves on the Right Bank of Kuban River. Drevnosti Kubani. Krasnodar, pp. 63-68. (in Russian).

Marina Z.P., Romashko V.I., 1984. Archaeological Excavations in the Mines Area of Western Donbass in 1984. Naukoviy arkhiv Instituta arkheologii NAN Ukrainy. 1984/147. (in Russian).

Moshkova M.G., 1963. The Sites of Prokhorovka Culture. Svod arkheologicheskikh istochnikov, iss. Д1-10. Moscow, Nauka Publ. 56 p. (in Russian).

Polin S.V., Simonenko A.V., 1990. The “Early” Sarmatian Graves in North Pontic Region. Issledovaniya po arkheologii Podneprov'ya. Dnepropetrovsk, DSU, pp. 76-95. (in Russian).

Symonenko O.V., 1994. The Early Sarmatian Period in North Pontic Region. Arkheolohiya, no 1, pp. 3248. (in Ukrainian).

Simonenko A.V., 2015. The Sarmatian Horsemen of North Pontic Region (2 ${ }^{\text {nd }}$ edition). Kyiv, Publisher Oleg Filuk Publ. 466 p. (in Russian).

Smirnov K.F., 1984. The Sarmatians and Approval of Their Political Domination in Scythia. Moscow, Nauka Publ. 184 p. (in Russian).

Shilov V.P., 1975. Essays on the History of Ancient tribes of Volga Region. Leningrad, Nauka Publ. 208 p. (in Russian).

Simonenko A.V, Marčenko I.I., Limberis N.Yu., 2008. Römische Importe in Sarmatischen und Maiotischen Gräbern Zwischen Unterer Donau und Kuban. Mainz, Verlag Philipp von Zabern. $626 \mathrm{~S}$. (in German). 
A.V. Symonenko. The Early Sarmatian Sites of the Orel-Samara Interfluve

\section{Information about the Author}

Aleksandr V. Symonenko, Doctor of Sciences (History), Leading Researcher, Institute of Archaeology, National Academy of Sciences of Ukraine, Prosp. Heroiv Stalinhrada 12, 04210 Kyiv, Ukraine, simonal@ukr.net, https://orcid.org/0000-0001-6878-556X

\section{Информация об авторе}

Александр Владимирович Симоненко, доктор исторических наук, ведущий научный сотрудник, Институт археологии Национальной академии наук Украины, просп. Героїв Сталінграда 12, 04210 г. Киев, Украина, simonal@ukr.net, https://orcid.org/0000-0001-6878-556X 